применение в отношениях банкротства терминов «контролирующие лица» и смежных с ним. Первый вполне уместно может быть применен в отношении привлечения к субсидиарной ответственности по долгам должника и при оспаривании сделок, в то время как термин заинтересованные лица может активно применяться в иных случаях необходимости учёта отступления от принципа автономии воли сторон.

$$
\text { **** }
$$

1. Федеральный закон от 26 октября 2002 г. № 127-ФЗ О несостоятельности (банкротстве): [в ред. от 31.12.2020] // С3 РФ. 2002. № 43. Ст. 4190.

2. Гражданский кодекс РФ (часть первая) от 30 ноября 1994 г. № 51-Ф3: [в ред. от 22.10.2020] // С3 РФ. 1994. № 32. Ст. 3301.

3. Сводные статистические сведения о деятельности федеральных арбитражных судов за 2018 г. // Режим доступа: http://www.cdep.ru/index.php?id=79\&item=5119 (дата обращения: 02.03.2021).

4. Сводные статистические сведения о деятельности федеральных арбитражных судов за 2019 год // Режим доступа: http://www.cdep.ru/index.php?id=79\&item=5257 (дата обращения: 02.03.2021).

5. Федеральный закон от 29 июля 2017 г. № 266-Ф3 «О внесении изменений в Федеральный закон «О несостоятельности (банкротстве)» и Кодекс Российской Федерации об административных правонарушениях» // СЗ РФ. 2017. № 31 (Часть І). Ст. 4815.

6. Ломакин Д.В. Концепция снятия корпоративного покрова: реализация ее основных положений в действующем законодательстве и проекте изменений Гражданского кодекса РФ // Вестник ВАС РФ. 2012. № 9. С. 32 .

7. Мусабирова Д.А., Ющенко Н.А. Меры, принимаемые для поддержки малого бизнеса, по законодательству о контрактной системе РФ и США // Вопросы экономики и права. 2018. № 115. C. 7-10.

8. Закон РСФСР от 22 марта 1991 г. № 948-1 «О конкуренции и ограничении монополистической деятельности на товарных рынках»: [ред. от 26.07.2006] // Ведомости СНД и ВС РСФСР. 1991. № 16. Ст. 499.

9. Полевая К.Д. Понятия «аффилированные лица» и «контролирующие лица» в антимонопольном, корпоративном и конкурсном законодательстве: компаративный аспект // Законодательство. 2017. № 5. С. $31-35$.

10. Обзор Президиума Верховного Суда РФ от 29 января 2020 г. судебной практики разрешения споров, связанных с установлением в процедурах банкротства требований контролирующих должника и аффилированных с ним лиц // СПС «КонсультантПлюс».

11. Постановление Девятого арбитражного апелляционного суда от 24 июня 2015 г. № 9АП24715/2015 // СПС «КонсультантПлюс».

\title{
Полякова Д.В.
}

\section{Использование полиграфа в расследовании и раскрытии преступлений}

Ростовский филиал ФГБОУ ВО «Российский государственный университет правосудия»

(Россия, Ростов-на-Дону)

doi: $10.18411 / \mathrm{j}-03-2021-236$

idsp: ljournal-03-2021-236

Научный руководитель

Полтавцева Л.И.

\section{Аннотация}

В статье исследуется вопрос использования полиграфа в расследовании и раскрытии преступлений. Отмечаются две наиболее часто встречаемые формы применения данного технического устройства: опрос (как оперативно-розыскное мероприятие) и экспертиза (как следственное действие). Делается вывод о том, что в связи с отсутствием единого научно-методического подхода $\kappa$ проведению психофизиологических исследований с использованием полиграфа, полученные с его помощью данные играют значительную роль только при проведении оперативнорозыскных мероприятий и следственных действий, выступая в качестве ориентира и вспомогательных средств, но они не имеют какую-либо доказательную ценность.

Ключевые слова: уголовное судопроизводство, раскрытие и расследование преступлений, полиграф, реакция опрашиваемого, опрос, экспертиза. 


\section{Abatract}

The article examines the use of a polygraph in the investigation and disclosure of crimes. The two most frequently encountered forms of application of this technical device are noted: interrogation (as an operational-search measure) and examination (as an investigative action). It is concluded that due to the lack of a unified scientific and methodological approach to conducting psychophysiological studies using a polygraph, the data obtained with its help play a significant role only when conducting operational-search measures and investigative actions, acting as a guide and auxiliary means, but they do not have any probative value.

Key words: criminal proceedings, disclosure and investigation of crimes, polygraph, response of the respondent, questioning, examination.

Качественные изменения в структуре современной преступности ставят перед правоохранительными органами задачу совершенствования существующих и разработки новых методов и эффективных приемов получения доказательной информации. Одним из таких средств является полиграф, история которого насчитывает несколько десятилетий, а если говорить о предпосылках его появления, то они уходят на несколько веков назад. Еще в древние времена разными народами было разработано множество особых техник и ритуалов для распознавания обмана и изобличения лжеца. Например, в Древнем Китае подозреваемого в преступлении подвергали рисовому тесту: ему приходилось брать в рот горсть сухого риса и выслушивать обвинение. Считалось, что, если рис оставался сухим во рту (слюноотделение приостанавливалось из-за боязни разоблачения), вина подозреваемого была доказана [3].

Современный полиграф - это техническое устройство, представляющее собой совокупность биомедицинских приборов, позволяющих синхронно и непрерывно фиксировать динамику психофизиологических реакций человека на вопросы, заданные экспертом (полиграфологом) [2, с. 153]. Данный прибор представляет собой пассивный регистратор процессов, происходящих в организме человека, позволяющий определять степень значимости для испытуемого раздражителей (вопросов), относящихся к различным обстоятельствам, например, это может быть информация о совершенном преступлении.

В наше время при раскрытии и расследовании уголовных дел все чаще прибегают к использованию полиграфа. Его можно использовать как при проведении опроса, так и при производстве специального психофизиологического исследования, так называемого психофизиологической экспертизы.

Опрос с использованием полиграфа как разновидность оперативно-розыскного мероприятия опрос- это нетравматичный, безвредный для жизни и здоровья человека комплекс действий (включая, в том числе, проверку на полиграфе), ориентированный на проверку полиграфологом достоверности информации, предоставленной опрашиваемым.

Проведение опроса с использованием полиграфа способствует:

1) получению от опрашиваемого фактических данных, важных для своевременного проведения оперативно-розыскных мероприятий и следственных действий, а также для выявления, предупреждения, пресечения и раскрытия преступлений;

2) осуществление розыска лиц, скрывающихся от органов дознания, следствия и суда или уклоняющихся от уголовного наказания, или пропавших без вести граждан;

3) оценки достоверности информации, предоставленной опрашиваемым лицом; 
4) проверке опрашиваемого лица на причастность к подготавливаемым или совершенным противоправным действиям.

Документом, подтверждающим проведение опроса с помощью полиграфа, является справка или акт (заключение), составленный полиграфологом и отправленный лицу, ведущему дело. В деле при проведении опроса на полиграфе должны содержаться следующие документы: 1) задание на его проведение; 2) заявление о добровольном согласии опрашиваемого на его проведение; 3) материалы проверки, содержащие сведения, относящиеся к цели расследования, сведения, предоставленные опрашиваемым в ходе опроса, относящиеся к целям расследования; 4) вид проверки и количество тестов (точно сформулированные вопросы и ответы опрашиваемого); 5) тестовые материалы [1, с. 402].

Пожалуй, одной из важнейших проблем применения полиграфа является процессуальная интерпретация результатов опроса с помощью полиграфа. Ряд ученых полагают, что эти результаты носят ориентирующий (розыскной) характер, другие, считают, что они должны иметь доказательственное значение.

Опрос на полиграфе - мероприятие добровольное, и полученные в результате данные влияют на ход уголовного судопроизводства. По-нашему мнению, информация, полученная в процессе опроса на полиграфе, имеет вспомогательное, ориентирующее значение для раскрытия и расследования преступления.

Кроме того, в судебно-следственной практике встречаются случаи, когда по постановлению следователя (дознавателя) или суда проводится психофизиологическая экспертиза, являющаяся самой оспариваемой формой получения информации с помощью полиграфа. НА. Селиванов считает, что «поскольку проверка на полиграфе требует использования специальных знаний и соответствующего исследования, есть все основания говорить о том, что в данном случае присутствуют все признаки такого процессуального действия, как экспертиза» [5, с. 27]. В.Ю. Шепитько, особого значения полиграфа не признает и считает, что «не исключены ошибки, которые могут возникнуть в процессе «экспертизы» в результате соответствующих ответных реакций опрашиваемого из-за пренебрежительного отношения к нему, неправильной постановки вопроса или демонстрации обвинительного уклона. Кроме этого, данные, полученные указанным образом, могут быть искажены или оказаться вероятными в силу того, что до испытуемого уже дошла информация о совершенном преступлении, в результате чего последний мог «накрутить» в своем сознании образы и совершенно поиному оценивать пережитые ранее события» [6, с. 198].

Судебная практика, как правило, не признает данные, полученные с помощью полиграфа, надлежащими и достоверными доказательствами по делу. В то же время встречаются случаи, когда суды ссылаются на результаты психофизиологической экспертизы и на их основании выносят приговоры [4, с. 165].

Уголовное судопроизводство, как и расследование преступлений, должно основываться на научно обоснованных и проверенных методах и средствах. И поэтому обязанность эксперта, прежде всего, - провести объективное исследование, основанное на научных данных и методах, а также на основе реальной исследовательской практики. Однако проблема в том, что на сегодняшний день нет единого научнометодического подхода к проведению психофизиологических исследований с использованием полиграфа. Поскольку смысл действия полиграфа - «уловить» реакцию человека на заданный вопрос, и эксперт на основании этих показаний делает вывод ложь или правда, то нельзя утверждать, что результаты такого исследования будут содержать необходимую информацию и служить надлежащим доказательством в уголовном деле. Этот процесс нельзя считать научным и стандартизованным, поскольку он основан на индивидуальных психических реакциях человека, которые могут различаться у нескольких субъектов при схожих обстоятельствах. Возможны также необоснованные отклонения от нормы показателей физиологических реакций, 
например, у людей с психическими расстройствами, тяжелобольных или пожилых людей (их ответные раздражители носят «замедленный характер»).

Таким образом, разработка процессуального порядка проведения исследований на полиграфе требует заблаговременного сбора большего количества теоретического и практического материала, основанного на использовании полиграфа в оперативнорозыскной деятельности. Хотя полиграф активно используется при раскрытии и расследовании преступлений, полученные с его помощью данные играют значительную роль только при проведении оперативно-розыскных мероприятий и следственных действий, выступая в качестве ориентира и вспомогательных средств, но они не имеют какую-либо доказательную ценность, именно поэтому этот метод раскрытия преступления крайне редко используется самостоятельно, то есть отдельно от других методов расследования.

1. Букаев H.M. Полиграф и гипноз: проблемы применения в уголовном процессе России // Совершенствование деятельности правоохранительных органов по борьбе с преступностью в современных условиях: Материалы Всероссийской научно-практической конференции. - Вып. 3. Тюмень: ТГАМЭУП, 2007.

2. Варламов В.А., Варламов Г.В. Психофизиология полиграфных проверок. Краснодар, 2000.

3. Игнатов С.В. «Вет» Вышинского // Медицинская газета. 1991. 21 апр.

4. Микелова Т.А. Значение данных, полученных с использованием полиграфа, в раскрытии и расследовании преступлений // Вестник современных исследований. 2018. № 12.6 (27).

5. Селиванов Н. А. Пособие для следователей. Расследование преступлений повышенной общественной опасности. - М.: Лига Разум, 1998.

6. Шепитько В.Ю. Проблемные лекции по криминалистике. Харьков: Апостіль, 2012.

\section{Полянская Д.А., Найденов Н.М. \\ Процессуальные проблемы стадии возбуждения уголовного дела}

Поволжский институт управления имени П.А. Столыпина

(Россия, Саратов)

doi: $10.18411 / \mathrm{lj}-03-2021-237$

idsp: ljournal-03-2021-237

\section{Аннотация}

В данной статье рассматриваются процессуальные проблемы стадии возбуждения уголовного дела. Авторы анализируют доводы как свидетельствующие о необходимости упразднения стадии возбуждения уголовного дела, так и, наоборот, о целесообразности существования данной стадии уголовного процесса.

Ключевые слова: уголовное дело, стадия возбуждения уголовного дела, уголовный процесс.

\section{Abstract}

This article deals with the procedural problems of the stage of initiation of a criminal case. The authors analyze the arguments both indicating the need to abolish the stage of initiation of a criminal case, and, conversely, the expediency of the existence of this stage of the criminal process.

Keywords: criminal case, stage of initiation of a criminal case, criminal process

Статья 6 Уголовно-процессуального кодекса РФ (далее - УПК) гласит, что главным назначением уголовного судопроизводства является защита прав и законных интересов лиц и организаций, потерпевших от преступлений. Механизм по реализации данного направления начинает свою работу уже на первой стадии уголовного судопроизводства - стадии возбуждения дела. В последнее время одним из наиболее обсуждаемых вопросов в сфере уголовного судопроизводства становится 